\title{
Numerical modelling of levee stability based on coupled mechanical, thermal and hydrogeological processes
}

\author{
Maciej Dwornik ${ }^{1, a}$, Krzysztof Krawiec ${ }^{2}$, Anna Franczyk ${ }^{1}$ and Andrzej Leśniak ${ }^{1}$ \\ ${ }^{1}$ AGH University of Science and Technology, Faculty of Geology, Geophysics and Environmental Protection, Al. Mickiewicza 30, \\ 30-059 Krakow, Poland \\ ${ }^{2}$ The Mineral and Energy Economy Research Institute of Polish Academy of Science, ul. Wybickiego 7, 31-261 Krakow, Poland
}

\begin{abstract}
The numerical modelling of coupled mechanical, thermal and hydrogeological processes for a soil levee is presented in the paper. The modelling was performed for a real levee that was built in Poland as a part of the ISMOP project. Only four parameters were changed to build different flood waves: the water level, period of water increase, period of water decrease, and period of low water level after the experiment. Results of numerical modelling shows that it is possible and advisable to calculate simultaneously changes of thermal and hydro-mechanical fields. The presented results show that it is also possible to use thermal sensors in place of more expensive pore pressure sensors, with some limitations. The results of stability analysis show that the levee is less stable when the water level decreases, after which factor of safety decreases significantly. For all flooding wave parameters described in the paper, the levee is very stable and factor of safety variations for any particular stage were not very large.
\end{abstract}

\section{Introduction}

Levees are a popular method for protecting areas against floods. There are over $8,000 \mathrm{~km}$ of levees along the main rivers in Poland [1]. The prevalence of this type of geotechnical structure makes levee monitoring a priority. Weak levees are dangerous for civil properties because they give a false impression of safety.

Nowadays, many people are looking for a universal and effective method for monitoring levee stability or predicting the time and place of their failure ([2-3]). Many projects (i.e. [4-5]) tried using thermal measurements (i.e. by using the properties of optical fibres to measure levee temperature) or other types of measurements to estimate fluid flow in levees. The aim of the ISMOP project (taken from the Polish title: Computer System for Monitoring River Embankments) is to create a complex threat forecasting system based on temperature and pore pressure sensors. To achieve this goal, an artificial full-size levee was constructed from materials commonly used for their construction.

Real measurements were preceded by numerical modelling for the mechanical, hydromechanical and thermal processes that occur during water level changes inside a water reservoir. In this paper, results of numerical modelling of the interactions between mechanical, hydromechanical and thermal processes are presented. These coupled numerical modellings were carried out in order to examine the influence of the flood wave process on the value of basic parameters that describe the state of the embankment.

\footnotetext{
${ }^{\mathrm{a}}$ Corresponding author: dwornik@geol.agh.edu.pl
}

\section{Object of the study}

The levee used to conduct field experiments was built in Czernichów near Krakow (Southern Poland) close to the Wisła River and its levees [6]. The size of the construction is $250 \times 50 \times 4.5 \mathrm{~m}$ and has the shape of a stadium containing a water reservoir (fig.1-2). A flood wave was simulated by changing the water level in the reservoir.

Geological conditions caused the necessity to preserve water migration into the geological medium: the watertight thin layer just under the levee. This artificial element causes fluid to flow only into the levee, not into the ground. The experimental levee was designed with a different shape on the right and left; the west side has identical slopes with a proportion of $1: 2$, whereas the east side has a slope on the water side with a proportion of 1:2.5 and an air slope with proportion 1:2. These two proportions are typical for earthen levees in Poland. The cross-section in the W-E direction was used for $2 \mathrm{D}$ numerical modelling. 


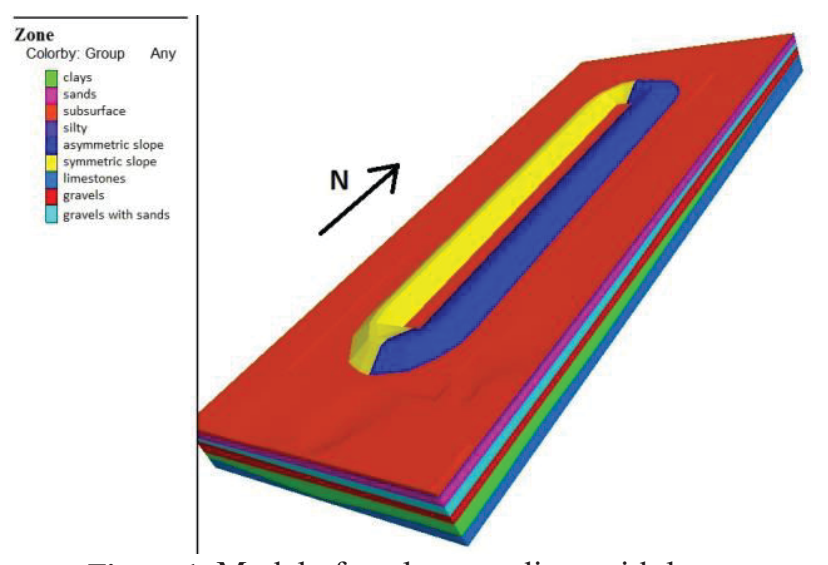

Figure 1. Model of geology medium with levee

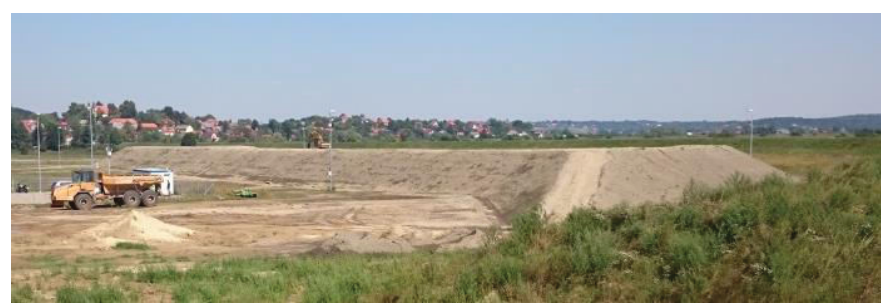

Figure 2. Photography of the experimental levee in Czernichów near Krakow (South Poland)

\section{Numerical modeling}

Numerical modelling was performed using Itasca Flac 2D 7.0 software. This software employs the finite difference method to solve geotechnical problems.

\subsection{Mathematical background}

The numerical code FLAC can be used to solve thermal-groundwater-mechanical problems [7]. All equations used in the FLAC code are described in the manual [7]. Some are listed below.

\section{Groundwater-mechanical coupling}

Fluid transport is described by Darcy's law

$$
q_{w}=-\mathbf{k} \nabla\left(\mathrm{P}-\rho_{w} g \cdot x\right)
$$

where $\mathbf{k}$ is fluid mobility coefficient (or "permeability" in FLAC terminology), $\rho_{w}$ is the fluid density and $\mathrm{g}$ is gravity. Fluid density in this equation is related to temperature changes as follows

$$
\rho_{w}=\rho_{0}\left[1-\beta_{f}\left(T-T_{0}\right)\right]
$$

where $T_{0}$ is the reference temperature and $\beta_{f}$ is the volumetric thermal expansion of the fluid.

The relation of permeability $\mathbf{k}$ to hydraulic conductivity $k_{H}$ is

$$
\mathbf{k}=\frac{k_{H}}{g \rho_{w}} .
$$

Three forces act on the solid matrix when fluid flows through a porous medium: solid weight, buoyancy, and drag or seepage force. All these forces are taken into account in the FLAC formulation. law

Heat transport in FLAC is described by Fourier's

$$
q^{T}=-k^{T} \nabla T
$$

where $k^{T}$ is the effective thermal conductivity defined in terms of the fluid $k_{w}^{T}$ and solid $k_{s}^{T}$ conductivities by the equation

$$
k^{T}=k_{s}^{T}+n S k_{w}^{T} .
$$

Heat is transferred in porous media by two processes in the FLAC implementation. There is forced convection when the heat is carried by fluid motion and free convection when fluid motion is caused by density differences due to temperature variations.

The energy balance equation used in FLAC for convective-diffusive heat transport is shown below.

$$
c^{T} \frac{\partial T}{\partial t}+\nabla q^{T}+\rho_{0} c_{w} q_{w} \cdot \nabla T-q_{v}^{T}=0
$$

where $\mathrm{T}$ is temperature, $q^{T}$ is thermal flux, $q_{w}$ is fluid specific discharge, $q_{v}^{T}$ is volumetric heat source intensity, $\rho_{0}$ is a reference density of the fluid, $c_{w}$ is a specific heat of the fluid and $c^{T}$ is the effective specific heat which is defined as

$$
c^{T}=\rho_{d} C_{v}+n S \rho_{0} c_{w}
$$

In the equation above $\rho_{d}$ and $C_{v}$ are solid matrix bulk density and bulk specific heat, respectively, $n$ is porosity and $S$ is saturation.

\subsection{Numerical model}

The numerical model was built from a $924 \times 70$ squared grid cell with a size of $0.1 \mathrm{~m}$. The depth of the model was $2.5 \mathrm{~m}$ below terrain level with $20 \mathrm{~m}$ of offset (distance from the edge of the model to the levee) to avoid a boundary effect. Vertical displacement was fixed on the bottom edge of model and the horizontal displacement was fixed on the left and right edges of model. Values of material parameters used in the calculations are presented in table 1.

All modelling was performed in four steps:

- calculation of mechanical equilibrium only for geological medium (without levee);

- calculation of mechanical equilibrium for geological medium and levee;

- calculation with one-hour step: firstly fluid transfer, then heat transfer, and lastly mechanical equilibrium. After each step water level and air temperature were updated to the new value;

- calculation of Factor of Safety.

The model with measurement points is presented in fig.3. The locations of these points are close to the real positions of the temperature and pore pressure sensors in the levee. For these points, plots of temperature and pore pressure are presented in next section. These points were located $0.4 \mathrm{~m}$ over terrain level and one $1 \mathrm{~m}$ from the top of the levee in both directions.

Thermal-groundwater coupling. 


\begin{tabular}{|c|c|c|c|c|c|}
\hline & $\begin{array}{c}\text { Symme } \\
\text { tric } \\
\text { levee }\end{array}$ & $\begin{array}{c}\text { Asymmet } \\
\text { ric } \\
\text { levee }\end{array}$ & $\begin{array}{c}\text { Subsur } \\
\text { face }\end{array}$ & Silty & Sand \\
\hline $\begin{array}{c}\text { Density } \\
{[\mathrm{g} / \mathrm{cm} 3]}\end{array}$ & 2.08 & 2.07 & 2.10 & 1.89 & 1.83 \\
\hline $\begin{array}{c}\text { Cohesion } \\
{[\mathrm{kPa}]}\end{array}$ & 16.9 & 24.1 & 10.3 & 13.7 & 9.75 \\
\hline $\begin{array}{c}\text { Friction } \\
{[\mathrm{deg}]}\end{array}$ & 37.6 & 35.6 & 32.9 & 22.5 & 35.8 \\
\hline $\begin{array}{c}\text { Bulk modulus } \\
{[\mathrm{MPa}]}\end{array}$ & 10.1 & 7.25 & 7.25 & 16.2 & 36.3 \\
\hline $\begin{array}{c}\text { Shear modulus } \\
{[\mathrm{MPa}]}\end{array}$ & 6.04 & 3.35 & 3.43 & 6.63 & 21.8 \\
\hline Porosity & $27 \%$ & $27 \%$ & $27 \%$ & $40 \%$ & $35 \%$ \\
\hline $\begin{array}{c}\text { Permeability } \\
{[\mathrm{m} / \mathrm{s}]}\end{array}$ & 1.18 & $\begin{array}{c}1.80 \\
\mathrm{x} 10^{-4}\end{array}$ & $\begin{array}{c}1.49 \\
\mathrm{x} 10^{-4}\end{array}$ & $\begin{array}{c}1.32 \\
\mathrm{x} 10^{-4}\end{array}$ & $\begin{array}{c}5.50 \\
\mathrm{x} 10^{-4}\end{array}$ \\
\hline $\begin{array}{c}\text { Specific heat } \\
{[\mathrm{J} / \mathrm{Kg} \mathrm{K}]}\end{array}$ & \multicolumn{5}{|c|}{840 for all geological medium and } \\
4189 for fluid \\
\hline $\begin{array}{c}\text { Thermal } \\
\text { conductivity } \\
{[\mathrm{W} / \mathrm{mK}]}\end{array}$ & \multicolumn{5}{|c|}{0.6 for fluid } \\
\hline
\end{tabular}

Table 1. Mechanical, hydromechanical and thermal properties using in modelling. Value cited after [7-8]

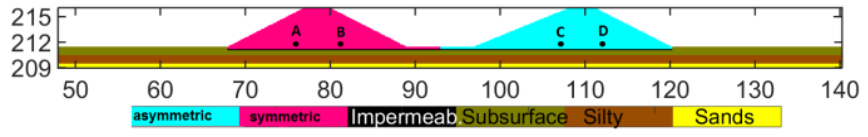

Figure 3. 2D model used in simulation [9]

\section{Results}

Seventeen numerical modellings were performed for different wave parameters: one modelling for a model with average wave parameters, and 16 modellings where only one of these parameters was changed. These parameters were (values in table 2): time of water level increase (from 0 to $3.5 \mathrm{~m}$ ), time of high water level $(3.5 \mathrm{~m})$, time of water level decrease (from 3.5 to $0.1 \mathrm{~m}$ ), and time of low water level $(0.1 \mathrm{~m})$. These times are a compromise between a typical flood wave and the power of the pumps used to fill the water reservoir.

\begin{tabular}{|l|l|l|}
\hline Stage of wave & $\begin{array}{l}\text { Average } \\
\text { model }\end{array}$ & Value used in test \\
\hline Increasing Wave & $48 \mathrm{~h}$ & $24,36,60,72 \mathrm{~h}$ \\
\hline High level $(3.5 \mathrm{~m})$ & $60 \mathrm{~h}$ & $12,24,60,84 \mathrm{~h}$ \\
\hline Decreasing Wave & $84 \mathrm{~h}$ & $54,66,90,126 \mathrm{~h}$ \\
\hline Low level $(0.1 \mathrm{~m})$ & $78 \mathrm{~h}$ & $24,48,96,144 \mathrm{~h}$ \\
\hline
\end{tabular}

Table 2. Time of wave's stages using in numerical modelling

Factor of Safety (FoS) [10] was calculated at the end of each stage of waves. This parameter was used to evaluate levee stability during the flooding process. Air temperature is presented in fig.4. Changing water levels for an average model during the experiment are presented in fig.5.

These plots show that thermal sensors were isolated from daily temperature changes and reacted only to water infiltration (see also fig.7-10). The first reaction to temperature changes is recorded at points $\mathrm{B}$ and $\mathrm{C}$ because they were located closer to the water reservoir. Reactions of sensors at points $\mathrm{A}$ and $\mathrm{D}$ were not as obvious as at B-C. At all points, thermal reaction is delayed compared to the reaction of pore pressure sensors (fig.6). This is due to the cooling of water during infiltration of the colder levee (initial temperatures of water and soil were $11^{\circ} \mathrm{C}$ and $8^{\circ} \mathrm{C}$ respectively). Displacements, calculated as displacements in vertical and horizontal directions for 1 hour, increased in the first stage of the wave. After reaching the high water level $(3.5 \mathrm{~m})$, the velocity of the displacements started to decrease for points $\mathrm{B}$ and $\mathrm{C}$. The increasing rate of displacements were still recorded in points $\mathrm{A}$ and $\mathrm{D}$, which are farther from water reservoir than points B and C. This rate decreased for all points when the water level fell. However, at low water level $(0.1 \mathrm{~m})$ some displacements were still recorded, mainly due to water movement inside the levee.

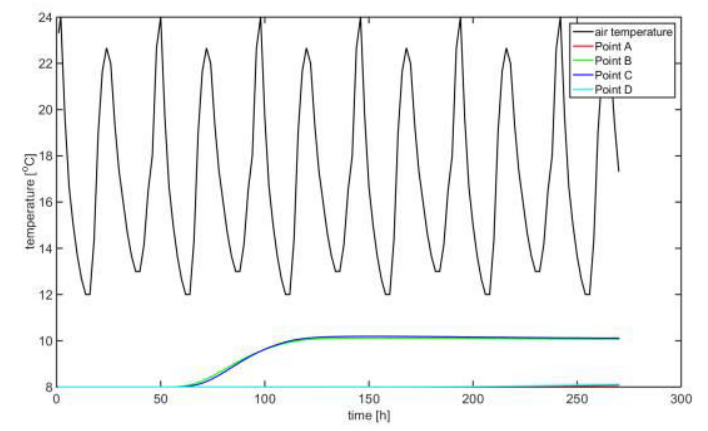

Figure 4. Air temperature and temperature modelled at point A$\mathrm{D}$ for average wave parameters. Initial soil temperature was $8^{\circ} \mathrm{C}$. Water temperature inside the reservoir was fixed at $11.04^{\circ} \mathrm{C}$

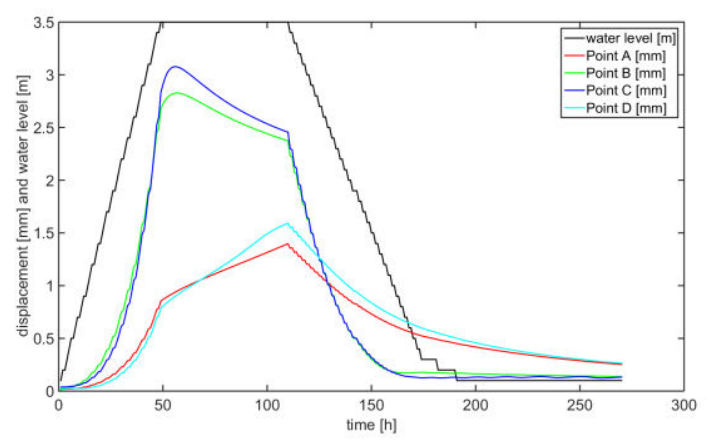

Figure 5. Water level $[\mathrm{m}]$ and length of displacement $[\mathrm{mm}]$ for model with average wave parameters

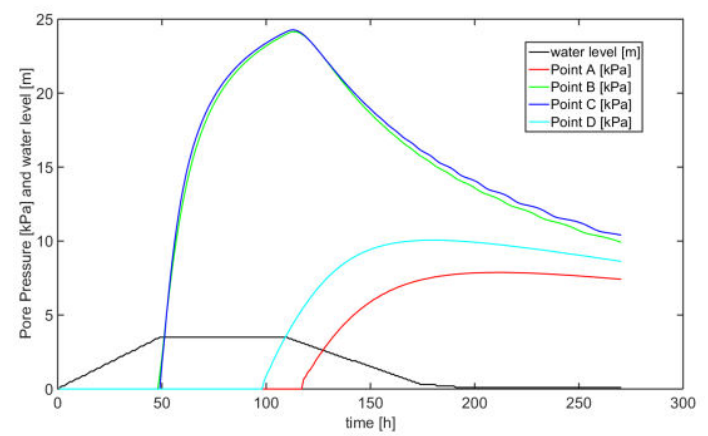

Figure 6. Pore pressure $[\mathrm{kPa}]$ modelled for points A-D for a model with average wave parameters and water level [m]

Figures 7-10 present displacement in a $1 \mathrm{~h}$ time window, pore pressure, and temperature after each stage for a model with average wave parameters. For these figures, it is clearly visible that the area of pore pressure anomalies (equivalent to non-zero water saturation in 
pores) does not correspond to the areas of temperature changes or displacements. After the first stage (increasing water level to $3.5 \mathrm{~m}$, fig.7), the biggest displacement values were observed in the asymmetric (right) levee wing and at the bottom of the reservoir. Pore pressure decreased at areas near the bottom of reservoir. The temperature increased in areas where there was contact with air or water.

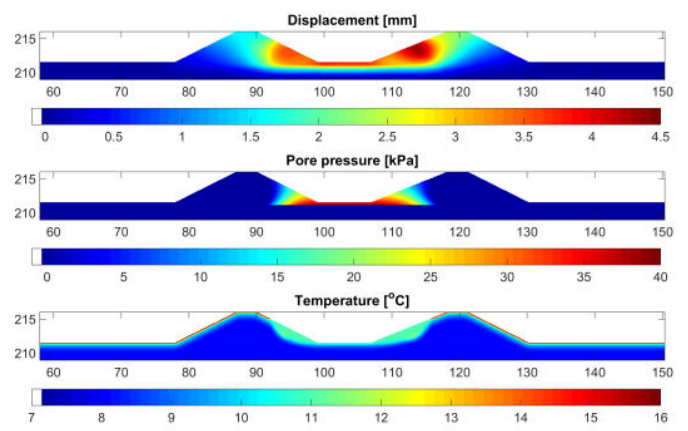

Figure 7. Displacement $[\mathrm{mm}]$, pore pressure $[\mathrm{kPa}]$ and temperature $\left[{ }^{\circ} \mathrm{C}\right]$ after end of increasing water level $(48 \mathrm{~h})$

After the high water stage in the water reservoir (fig.8), pore pressure isolines were almost elliptical. The maximum water flow is recorded over the impermeability layer. Maximum displacement was still visible at the bottom of the reservoir, but also at the top of the right levee. Temperature changes were smaller than the range of water infiltration.

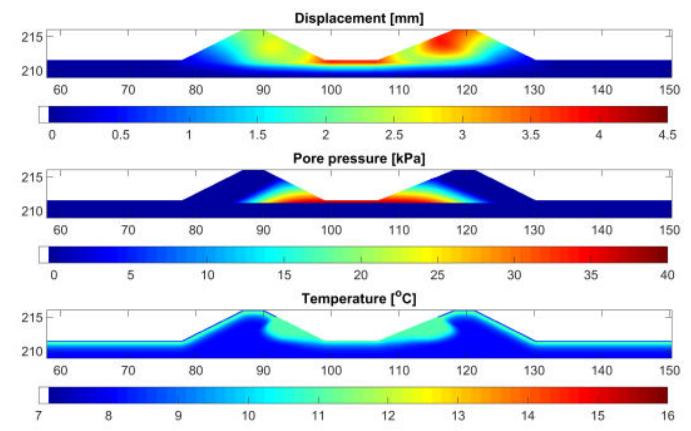

Figure 8. Displacement $[\mathrm{mm}]$, pore pressure $[\mathrm{kPa}]$ and temperature $\left[{ }^{\circ} \mathrm{C}\right]$ after end of high water level $(108 \mathrm{~h})$

The process of falling water level reduces the value of displacements and pore pressure (fig.9). Only the areas where the temperature rose above the initial $8^{\circ} \mathrm{C}$ expanded. These changes were caused by air-soil convection and water infiltration. This conclusion is also true for the last stage (low water level, fig.10). Displacement is close to zero and water consequently escapes outside the levee on the top of the impermeable layer. Because of the difference between soil and air temperature, the range of temperature changes from air increased.

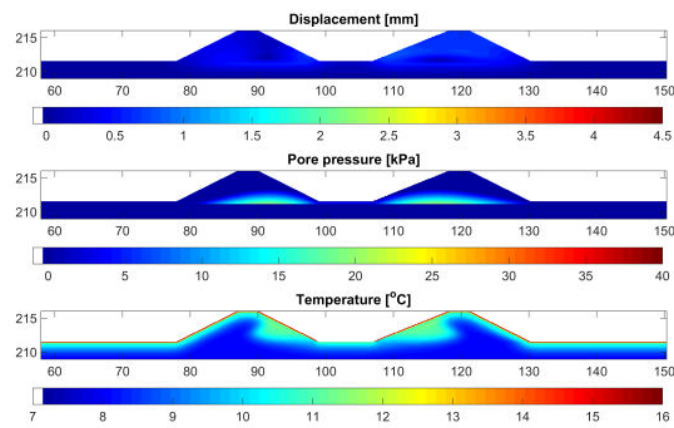

Figure 9. Displacement $[\mathrm{mm}]$, pore pressure $[\mathrm{kPa}]$ and temperature $\left[{ }^{\circ} \mathrm{C}\right]$ after water level had stopped falling $(192 \mathrm{~h})$

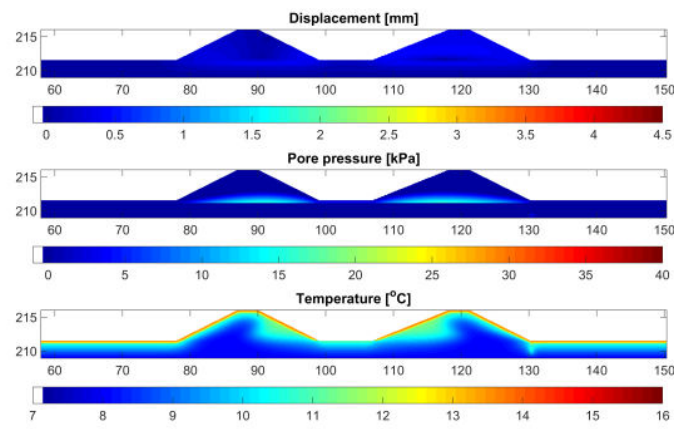

Figure 10. Displacement $[\mathrm{mm}]$, pore pressure $[\mathrm{kPa}]$ and temperature $\left[{ }^{\circ} \mathrm{C}\right]$ at the end of numerical modelling $(270 \mathrm{~h})$

For all numerical modellings, factor of safety was calculated at the end of each stage. The results of these calculations are presented in table 3. For all tested cases, the levee was stable $(\mathrm{FoS}>1)$. The lowest $\mathrm{FoS}$ value was obtained when the process of removing water from reservoir was the fastest. This stage caused a stability reduction from 3.5 to 3.0 .

\begin{tabular}{|l|r|l|r|r|}
\hline & $\begin{array}{l}\text { After } \\
\text { increasing } \\
\text { water level }\end{array}$ & $\begin{array}{l}\text { After } \\
\text { stage of } \\
\text { high } \\
\text { water } \\
\text { level }\end{array}$ & $\begin{array}{l}\text { After } \\
\text { decreasing } \\
\text { water level }\end{array}$ & $\begin{array}{l}\text { After } \\
\text { stage of } \\
\text { low } \\
\text { water } \\
\text { level }\end{array}$ \\
\hline $\begin{array}{l}\text { Average } \\
\text { model }\end{array}$ & 3.521 & 3.521 & 3.026 & 3.190 \\
\hline Vary time & 3.521 & 3.521 & 3.029 & 3.193 \\
of & 3.521 & 3.521 & 3.029 & 3.190 \\
increasing & 3.521 & 3.521 & 3.020 & 3.184 \\
water & 3.521 & 3.506 & 3.017 & 3.181 \\
\hline Vary time & 3.521 & 3.521 & 3.108 & 3.254 \\
of high & 3.521 & 3.521 & 3.079 & 3.234 \\
water level & 3.521 & 3.521 & 3.000 & 3.164 \\
& 3.521 & 3.521 & 2.973 & 3.140 \\
\hline Vary time & 3.521 & 3.521 & 2.964 & 3.167 \\
of & 3.521 & 3.521 & 2.991 & 3.175 \\
decreasing & 3.521 & 3.521 & 3.035 & 3.190 \\
water & 3.521 & 3.521 & 3.079 & 3.210 \\
\hline Vary time & 3.521 & 3.521 & 3.026 & 3.090 \\
of low & 3.521 & 3.521 & 3.026 & 3.140 \\
water level & 3.521 & 3.521 & 3.026 & 3.210 \\
& 3.521 & 3.521 & 3.026 & 3.260 \\
\hline
\end{tabular}

Table 3. Factor of Safety for different wave shapes. Time of wave stages are presented in table 2. The value of FoS is presented in order from the shortest to the longest wave stage time of each stage. 
The duration of the first stage (increasing water level) had almost no effect on the FoS value after the end of the experiment (varies from 3.181 to 3.193). The biggest difference for the final FoS value was observed for high water level (varies from 3.14 to 3.25 ) and low water level (from 3.09 to 3.26). The long low water level duration causes levee stability to be closer to the state before the experiment.

\section{Conclusions}

The results of numerical modelling show that it is possible to calculate simultaneously the values of thermal and hydro-mechanical fields. The presented results show that it is possible to use thermal sensors instead of more expensive pore pressure sensors, with some limitations. The sensors should be placed in areas where there is no effect of daily temperature changes. In addition, the reaction of the sensor to water infiltration is later than the pore pressure sensors, mainly due to energy exchange between soil and water during infiltration.

Analysis of stability shows that the levee is less stable when water level is decreasing. The factor of safety at the end of this stage decreases from 3.5 to 3.0. Of course, for all tested flood wave parameters, the levee is very stable and the difference between FoS for one particular stage was not large (mainly less than 5\%).

\section{Acknowledgements}

This work is financed by the National Centre for Research and Development (NCBiR), Poland: project PBS1/B9/18/2013 (no 180535).

This work was partly supported by AGH University of Science and Technology, Faculty of Geology, Geophysics and Environmental Protection, as a part of statutory research project.

\section{References}

1. Borys M. (2007). Przepisy i wymogi oraz aktualny stan obwałowań przeciwpowodziowych w Polsce. Woda - Środowisko - Obszary Wiejskie, 20(7), 25-44

2. www.urbanflood.eu

3. www.ijkdijk.eu

4. Radzicki, K. and Bonelli, S. (2012). Monitoring of the suffusion process development using thermal analysis performed with IRFTA model, w Proc. of 6th ICSE, 593-600.

5. Bukowska-Belniak, B., Dwornik, M., Pięta, A. and Leśniak, A. (2015). A 2D model of temperature changes in experimental embankment. Measurement, Automation, Monitoring, 61(6), 233-236

6. Mościcki J.W., Bania, G., Ćwiklik, M. and Borecka A. (2014). DC resistivity studies of shallow geology in the vicinity of Vistula river flood bank in Czernichów Village (near Kraków in Poland). Studia Geotechnica et Mechanica. 36 (1), 63-70
7. Itasca Consulting Group, I. (2011). FLAC Fast Lagrangian Analysis of Continua and FLAC/Slope User's Manual.

8. Borecka, A., Kaczmarczyk, R., Krokoszyński, P., Ptaszek, M., Stanisz, J., Korzec, K., Kret, E., Tchórzewska, S., Nowak, P., Światek, M., Pękala M. and Dąbrowski J. (2014). Dokumentacja geologiczno-inżynierska wraz z dokumentacja badan podtoża gruntowego sporządzona $w$ celu określenia warunków geologiczno-inżynierskich dla projektowanej budowy eksperymentalnego watu przeciwpowodziowego na dzialce $n r \quad 796$ w Czernichowie. AGH-UST internal documentation

9. Dwornik, M., Krawiec, K., Pięta, A. and Leśniak, A. (2015) Numerical and experimental stability analysis of earthen levees. IAMG 2015: the 17th annual conference of the International Association for Mathematical Geosciences : Freiberg, Germany, Short Abstract: 163-164, Full Paper (DVD): 857-864

10. Cala, M., Flisiak, J. and Tajduś, A. (2004). Slope stability analysis with modified shear strength reduction technique. In: Proceedings of the Ninth International Symposium on Landslides'04, Rio de Janerio, A.A. Balkema Publishers, London, 10851089. 